Research Paper

\title{
Carbon dynamics of a warm season turfgrass using the eddy-covariance technique
}

\author{
Roshani Pahari ${ }^{\mathrm{a}}$, Monique Y. Leclerc ${ }^{\mathrm{a}, *}$, Gengsheng Zhang ${ }^{\mathrm{a}}$, Hafsah Nahrawi ${ }^{\mathrm{a}, \mathrm{b}}$, Paul Raymer \\ a Atmospheric Biosciences Group, Department of Crop and Soil Sciences, The University of Georgia, Griffin, GA, 30223, United States \\ b Faculty of Resource Science and Technology, Universiti Malaysia Sarawak, 94300, Malaysia \\ ${ }^{\mathrm{c}}$ Department of Crop and Soil Sciences, University of Georgia, Griffin, GA, 30223, United States
}

\section{A R T I C L E I N F O}

\section{Keywords:}

Eddy-covariance method

Carbon budget

Carbon sequestration

$\mathrm{CO}_{2}$ fluxes

Net ecosystem exchange

Gross primary productivity

Warm season turfgrass

Canopy coverage

Sod

\begin{abstract}
A B S T R A C T
Despite their ubiquitous presence in the urban landscape throughout the United States, scant attention has been given to evaluate the magnitude of net carbon balance from turfgrasses. Warm season turfgrasses, in particular, have largely been understudied for their carbon sequestration potential. With questions being frequently raised on the environment friendliness of warm season turfgrasses, detailed and robust studies focusing on the carbon behavior of such systems are warranted. This study delves into the carbon balance of 'Tifway' bermudagrass, the extensively used warm-season turfgrass in Georgia and other subtropical and warm temperate areas. Using the eddy-covariance method, the amount of $\mathrm{CO}_{2}$ captured by a highly managed turfgrass system was measured by deploying two eddy-covariance systems for the study period of 31 months. The results show that 'Tifway' bermudagrass is a net sink of carbon, sequestering it at the rate of $4.51-5.15 \mathrm{Mg} \mathrm{C} \mathrm{ha}^{-1} \mathrm{yr}^{-1}$. The turf canopy as well as management activities carried out in the farm appear to have a powerful influence on the carbon behavior of the turf. Seasonal and monthly fluxes suggest that turf is an efficient assimilator of carbon during its active growth period of summer and fall months. The results show that the turf sequestered higher amounts of carbon than many agricultural crop systems, supporting the assertion that it is an efficient assimilator of atmospheric carbon.
\end{abstract}

\section{Introduction}

The world's population is increasingly concentrated in urban areas, leading to recent expansion in urban and built-in land use. By the end of 2014, fifty-four percent of the world's population was living in urban areas and this number is expected to increase to sixty-six percent by 2050 (data.worldbank.org). The proportion of the urban population is even higher (about $82 \%$ as of 2015) in the United States (data. worldbank.org). With urbanization, much of the pervious landscape (e.g. forests, agricultural lands) are being converted to both impervious surfaces (e.g. concrete) and to less pervious lands such as lawns, golf courses. Turfgrasses cover a land area of enormous magnitude in cities and megacities. They covered about 163,800 square kilometers, three times the area covered by irrigated corn, in the United States and about 5688 square kilometers in Georgia alone (Milesi et al., 2005). Currently, they make up about $20-30 \%$ of the urban landscape (Nowak et al., 2013). With the continued expansion of urban areas, the increasing percentage of land throughout the United States is expected to be converted into home lawns, recreational parks, golf courses and other greenbelts (Bandaranayake et al., 2003; Lorenz and Lal, 2009; Milesi et al., 2005; Qian and Follett, 2002). The rapid expansion of turfgrasses in the ever-growing urban areas not only exemplifies its popularity, but also highlights the necessity of research assessing its impact on the urban ecosystem.

Turfgrasses dominate a significant part of the urban landscape and it continues to expand, yet, carbon (C) exchange from these systems is poorly understood. Specifically, the C exchange from warm season turfgrasses like bermudagrass, that cover a significant part of urban lawns in southern United States (Duble, 1996), are understudied (Fissore et al., 2012; Wu and Bauer, 2012). Much of the previous turf related research were focused on cool season grasses (Bremer and Ham, 2005; Wu and Bauer, 2012) and only a few studies were related to warm season grasses (Dugas et al., 1999). In addition to their growing acreage in tropical, subtropical and warm temperate urban areas, their long growing season and highly efficient $\mathrm{C}_{4}$ photosynthetic pathway make warm season turfgrasses an ideal system to study C behavior. In addition, they are characterized by dense canopy and extensive root system, making them one of the potentially effective $\mathrm{C}$ assimilating systems.

Turfgrasses offer a great advantage to the urban environment by

\footnotetext{
* Corresponding author

E-mail address: moniqueleclerc@moniqueleclerc.org (M.Y. Leclerc).
} 